\title{
Two Sets of Business Cards: \\ Responses of Chinese Immigrant Women Entrepreneurs in Canada and Australia to Sexism and Racism
}

\author{
Frances Chiang \\ Kwantlen Polytechnic University \\ Angeline Low \\ University of Technology Sydney \\ Jock Collins \\ University of Technology, Sydney
}

\begin{abstract}
Existing entrepreneurial discourses have been dominated by white middle-class androcentric approach, giving little space to the discussions of racism and sexism experienced by minority women entrepreneurs. This paper aims to fill this gap through an examination of the experiences of Asian immigrant women entrepreneurs in Canada and Australia using an intersectional approach. The key research question addressed in the paper is to what extent, and in what ways, do racism and sexism impact on the entrepreneurial experiences of Asian immigrant women entrepreneurs and what strategies do they use in managing discrimination to protect themselves and their businesses? Four main strategies were derived from our findings, namely, creating a comfortable niche, playing the mainstream card, swallowing the pain, and resisting.
\end{abstract}

\section{Introduction}

This paper examines the experiences of Asian immigrant women entrepreneurs in Canada and Australia. The point of departure is the growth in the number of immigrant women who have become entrepreneurs, that is, who have moved into self-employment by taking over an existing business enterprise or starting up a new enterprise. This is itself the result of the intersection to three related international trends. The first is the growth in entrepreneurship per se, mainly because of a renaissance of the small business sector over the past four decades, particularly in the USA, Australia and Canada (Light \& Rosenstein 1995, pp.12-3; Hindle \& O'Connor 2005, pp. 1-2). The second trend is the growing importance of female entrepreneurship. While female participation in entrepreneurship varies significantly across countries (Minniti et al. 2005), it has been particularly strong, and growing, in Australia and Canada. In Canada, the numbers of women who were in self-employment or owned their own business increased fourfold over the decades between 1976 and 1997 (Hughes 1999). OECD data for participation rates as employers and own account workers for 1976, 1986 and 1996 for 19 selected OECD countries shows that Australia had the fourth highest rate of participation in small businesses (32.8 per cent) after Canada (41.2 per cent), the USA at 39.2 per cent and Mexico (36.1 per cent) and that women exceeded 30 per cent of all entrepreneurs in 11 of these countries (OECD 1998, p. 25). The third trend is the increasing Cosmopolitan Civil Societies Journal, Vol.5, No.2, 2013 
importance of immigrant entrepreneurship (Light 1972; Waldinger et al. 1990; Light \& Rosenstein 1995; Light \& Gold 2000; Rath 2000; Kloosterman \& Rath 2003). This is particularly the case in many high immigration countries such as Australia, Canada and the United States, where immigrants manifest a higher rate of self-employment and entrepreneurship than their non-immigrant counterparts (Light \& Rosenstein 1995). In Australia 25.8 per cent of all self-employed are foreign-born, higher than all the major OECD countries other than Luxembourg (OECD 1998, p. 36).

The entrepreneurship literature has traditionally been dominated by a white middle-class androcentric approach, concentrating on the way that women support the entrepreneurial activities of their male spouses, partners or relatives and ignoring or underestimating the experiences of women who are entrepreneurs in their own right. As a consequence the experiences of women entrepreneurs who come from minority racial or ethnic backgrounds are particularly ignored, despite the fact that the rate of entrepreneurship among minority racial or ethnic backgrounds is often higher than for other women. Until recently most women entrepreneurial discourses, under the influence of masculine scholarship, presented women's entrepreneurial development as a process of 'othering,' and depicted women entrepreneurs as inferior to their male counterparts (Bruni, Gherardi \& Poggio 2005). When focusing on the experiences of women, these discourses were mostly seen through the lens of white middle-class women, failing to give space to women of colour (Knight 2005). Indeed, variations among women entrepreneurs and the invisible barriers they faced have not been adequately addressed (see for example, Hauge \& Havnes 2005). Based on the relatively privileged histories of white middle-class women, most studies of entrepreneurial women emphasised the notions of independence and autonomy, self-determination and personal growth, hence undermining the labour histories of working-class women and women of colour (Knight 2005). In addition, 'the networking discourses are often framed as racially neutral and classless', with the assumption that 'all women have the ability of acquiring or being a part of thriving networks' (Knight 2005, p.156). Even when this 'mainstream' entrepreneurship literature engages women entrepreneurship, it does so without reference to the immigrant entrepreneurship literature that has the potential to throw considerable light onto the experience of immigrant women entrepreneurs. These two strong traditions of entrepreneurship scholarship appear to live 'parallel lives,' not connecting with each other. 
Meanwhile, while the ethnic entrepreneur scholarship has long recognized diversity among racial and ethnic groups who become entrepreneurs, it has tended to ignore the contributions of immigrant and ethnic women. Like the mainstream entrepreneurship scholarship, immigrant women are studied, in the main, as important contributors to the activities of male immigrant entrepreneurs, but not as entrepreneurs in their own right. The immigrant entrepreneurship literature, which focuses on the way that different immigrant experiences of entrepreneurship are embedded within family and ethnic community networks locally, nationally and internationally, as well as within regimes of governance, regulation and policy (Kloosterman \& Rath 2001), has been mainly concerned with male immigrant entrepreneurs. While the contradictory aspects of classism and racism, and class and ethnic resources have been brought to the centre of understanding (Light \& Rosenstein 1995), the androcentric nature of such discourses has marginalised the experiences of ethnic minority women and the gendered nature of entrepreneurship. As Apitzsch commented, 'Women remain the 'hidden side' of the success story of ethnic entrepreneurship' and 'need to be more generally recognized as agents' (Apitzsch 2003, p.169). Asian women entrepreneurs, in particular, are deemed invisible in entrepreneurial discourses with only a few studies that focused on them (Dhaliwal 1998; Kang 1996, 2003). Further, the integrated aspects of race, ethnicity, gender, and class have rarely been dealt with in studies relating to the entrepreneur, and issues of racism and sexism have been silenced in most entrepreneurship discourses (Greer \& Greene 2003).

In the literature on ethnic and/or women entrepreneurship, discrimination, manifested as underemployment and blocked mobility due to accent and glass ceilings, often played a key role in explaining the dynamics of entrepreneurship amongst immigrant minorities and ethnic women. Immigrants who could not achieve labour market outcomes commensurate to their human capital because of individual or institutional racial and sexual discrimination were 'pushed' into self-employment. By setting up their own business enterprise they had the opportunity not only to earn more but to also to escape prejudice entrenched in the culture of the workplace (Aldrich \& Waldinger 1990; Castles et al. 1991; Collins \& Castles 1992; Collins et al. 1995; Light \& Rosenstein 1995; Peters 1999; Light \& Gold 2000; Pio 2007). Although the literature offers an explanation as to why some immigrants go into business to escape discrimination in the workplace, it rarely looks into the discrimination these individuals face after entry into entrepreneurship and further fails to examine how immigrants respond to discrimination in their own businesses. 
This paper will attempt to fill these gaps by bringing the diverse experiences of Asian immigrant women entrepreneurs in Australia and Canada to the centre of analysis. By adopting an intersectional approach, our primary focus is to investigate the nature of their experiences of racism and sexism, the impact on themselves and their businesses, and their responses to it.

\section{Conceptualising Asian Immigrant Women Entrepreneurs in a National Context}

The literature on immigrant entrepreneurship has rarely focused on immigrant women and entrepreneurship, with little recent research published in the field (Collins and Low 2010). This paper is based on the narratives of Asian immigrant women entrepreneurs in Sydney, Australia and Chinese immigrant women in Richmond, Metro Vancouver, Canada, collected via two independent studies. By coining our group of women as Asian we run the risk of using a western imperialistic lens of reductionism and overgeneralization. As Lee (2006) argued, Asia is 'a European invented term to refer to certain geographically locatable territories and cultures' outside of Europe and 'Asians [as] a generalized Other to Europeans, who see "Asian-ness" as a strange and exotic way of being...' (Lee 2006, p.23). Bearing this in mind, it is important to acknowledge that the adoption of Asian as a group in this paper does not downplay their multiplicity and heterogeneity but is solely for analytical purposes. Asian women, therefore, were defined according to geographical locations based on European construction; and Asian immigrant women in the Canadian and Australian contexts referred to non-native women born in Asia.

Although the women entrepreneurs in our studies came from diverse backgrounds, and were half a globe apart, the results on the aspects of racism and sexism yield considerable commonalities. Needless to say, though minority immigrants arrive at the host societies for different reasons, Australia and Canada share similar histories of imperialism and colonialism, patriarchy, immigration and immigrant settlement (Adelman et al. 1994a; 1994b) including a common history of racialised immigration policy and racialised histories of minority immigrant settlement, particularly in relation of Asian immigrants (Collins \& Francis 1994). A comparative study of Asian women entrepreneurs in Australia and Canada holds the potential to highlight the commonalities and differences of their experiences across transnational and transcultural spaces, thus contributing to the understanding of how gender, 
race, ethnicity and class intersect to shape the lives and businesses of women entrepreneurs and their experiences of, and responses to, racism and sexism.

Asian immigrants, particularly those from China, have a long history of entrepreneurship in Canada (Li 1988) and Australia (Collins 2002). Before World War II, the white Australia and white Canada immigration policies that restricted Chinese entry into both countries (Collins \& Henry 1994) were accompanied by formal and informal racist legislation and practices that either prevented their entry into paid employment or confined them to menial, manual, low paying jobs. Most turned to establishing their own business, often restaurants, furniture shops and factories, market gardens and retail activities. This is a classic case of the 'push' to entrepreneurship by the blocked mobility that was derived from racist exclusion. Both countries abandoned racist immigration policies in the 1960s (Canada) and early 1970s (Australia). A non-discriminatory immigration policy was introduced, with Australia adopting Canada's points system to select immigrants. In the last two decades, Chinese and other Asian immigrants featured prominently in the immigration intakes of both countries, though most arrive as skilled migrants with university educations and professional skills and are able to find high paying jobs in the service sector in the major cities of Vancouver, Toronto, Sydney, Melbourne, Brisbane and Perth. While anti-Asian sentiment is enduring in both countries, it has reduced substantially so that blocked mobility is today a more subtle, and different dynamic in the entrepreneurial story of Asian immigrants in Australia and Canada than it was more than a century ago.

There has been some important research into Asian entrepreneurs in Australia. Lever-Tracy et al. (1991) surveyed 104 Chinese and 40 Indian entrepreneurs with businesses in retail trade (including take-away food shops), restaurants, wholesale trade, property and business services and health in Brisbane and Sydney. The survey found that both the Chinese and Indian business owners surveyed had to confront 'a residue of prejudice and discrimination and a battery of obstacles to the recognition of overseas qualifications' during the process of applying to emigrate to Australia (Lever-Tracy et al. 1991, p. ix). Stromback and Malhotra (1994) surveyed 45 South Asians who were business owners in the Western Australian capital city of Perth. This study reinforces the 'blocked mobility' hypothesis because many entrepreneurs surveyed reported difficulties in having their qualifications recognized in Australia, problems in gaining admission into professional bodies and 'more subtle influences' which prevented them from fully utilizing their skills in Australia: 'As a result of such 
problems many South Asians start their own businesses' (Stromback \& Malhotra 1994, pp. xxi). Both of these studies focused on male Chinese immigrant entrepreneurs. Very few studies - the exception is Ip and Lever-Tracy $(1991,1992)$ - looked at Asian women entrepreneurs.

On the Canadian front, recent notable research on Asian immigrant entrepreneurship include Li's (2001) work on Chinese immigrant business, Wong and Ng's (2002) work on Chinese immigrant entrepreneurs, Wong’s (2004) research on Taiwanese immigrant entrepreneurs, and Karl Froschauer and Lloyd Wong’s (2006) study on transnational businesses among South Asian and Chinese immigrants. Using the 1996 census data, Li (2001) found that both Chinese immigrant men and women are drawn into business as a result of 'blocked mobility' when compared with their native born counterparts who are more likely to consider entrepreneurship as a viable option. Similar to Li's findings, Wong and Ng (2002) support the significance of structural constraints and blocked mobility in the mainstream economy that relegates Chinese immigrant entrepreneurs in Vancouver to the ethnic economy. In addition, they noted the significance of transnationalism in fostering immigrant businesses. Extending on this notion, Wong (2004) studied the impact of transnational businesses and networks among Taiwanese immigrant entrepreneurs and noted that these entrepreneurs have a tendency to operate on transnational social space emphasising transnational familial networks, transnational business circuits and transmigration. Further on the development of transnationalism, Froschauer and Wong (2006) studied new transnational Chinese and Indian immigrant men and women entrepreneurs who benefit from the growth of high technology development in the Asia Pacific locations and acknowledge the importance of social capital in terms of transnational network and social space between Asia and Western Canada. While these studies include both men and women in their analysis, sole attention on the experiences of Asian/Chinese immigrant women entrepreneurship is rare. Despite the wide recognition of blocked mobility in explaining entrepreneurship, the experiences and subsequent responses to discrimination is virtually non-existent in entrepreneurial scholarship.

\section{Intersectionality and Entrepreneurial Scholarship}

The concept of intersectionality denotes an integrative model that focuses on the analysis of minorities or the 'other,' and the multiplicity of oppression. Discourses on intersectionality build from anti-racist feminist thought that is highly critical of the masculinist western 
traditions and the non-representation or misrepresentation of white feminists in explaining the experiences of women of colour. The vast majority whose work is based on this perspective (see for example, Anthias \& Yuval-Davis 1992; Yuval-Davis 1996; Dua \& Robertson 1999; Hellwig \& Thobani 2006; Massaquoi \& Wane 2007) take note of the fact that the experiences of minority women are not uniform, but complex and diverse, as a result of their differential locations in the interlocking historical contexts of imperialism, colonialism, patriarchy, and capitalism. This perspective recognises women as agents intersecting with structural forces most commonly expressed in the intersection of race, class and gender, and correspondingly interested in the analysis of intertwining and interlocking experiences of racism, classism, and sexism. This can be extended to include other socio-cultural-political categories such as ethnicity, sexuality, disability, and nationality. Intersectionality challenges the essential, ahistorical, fixed, independent, and quantitative nature of social categorizations from which one category compete for primacy and importance over the other. Rather, it emphasises the fluidity of social construction in producing and reproducing unique experiences and social relations. Hence, the experiences of Chinese immigrant women entrepreneurs in Australia would be different from that of Filipino domestic workers, or Aboriginal women; the oppressions experienced by black women in the United States would be different from those experienced by Caribbean or Ghanaian women in Canada.

Taking an intersectional standpoint, we argue that incidents of racism may be sexualised, and those of sexism are likewise racialised, as well as classed. For example, as victims of racism, minority women are targeted because of their integrated identity as Asian, women, women of colour, and the rich or the poor. Similarly, as victims of sexism, these women are targeted not just because of their gender but also because of their race, ethnicity, and class locations. Moreover, racism and sexism interplay to produce stereotypes and misrepresentations. For instance, Asian women are often portrayed as binary oppositions in the media: exotic, subservient, compliant, industrious, and eager to please on the one hand, and 'Dragon Ladies' and 'Warrior Women' on the other (Jiwani 2006). They are often perceived as naturally inferior, socially unimportant, belonging to a ghettoized work force capable of doing only low-paid work, but at the same time, viewed as 'model minorities' (Hellwig \& Thobani 2006) when targeted for their hard work, accomplishments, and wealth.

Using intersectionality to understand entrepreneurial behaviour of minority women, therefore, involves analyses of continuously evolving processes relative to various intertwining socio- 
economic-political characteristics, with a focus on the 'agency' of minority women who actively shape their own lives within these broader structural constraints.

However, existing entrepreneurial projects rarely identify the need to address diversity and difference among women entrepreneurs. Despite the call for recognition of race, sex, and class in entrepreneurship (Beggs, Doolittle \& Garsombke 1994), discourses and research in this area are rather scarce. One study showed how gender resources intersect with class and ethnicity among Iranian immigrant women entrepreneurs in Los Angeles (Dallafar 1994). Another study focused on language dynamics in everyday interaction based on race, gender and class of Korean nail salon owners in New York City (Kang 1997). Kang (2003) further explored how diverse racial and class locations call for different forms of gendered emotional management among these Korean nail salon owners. Anthias and Mehta (2003) reported on how family resources operated differently between men and women entrepreneurs when studying the interconnections of gender, ethnicity, and the family. Harvey (2005) studied how black working-class women entered into the hair and beauty businesses by taking an intersectional lens of race, class and gender. More recently, Essers and Benschop (2009) studied Muslim businesswomen by analyzing the intersection of gender, ethnicity, and religion, documenting how these women take charge in stretching beyond Islam crisscrossing with their ethnic and gender identities in their entrepreneurial work.

When comparing with the existing literature on women and ethnic entrepreneurship, the intersectional approach provides a richer, deeper and more nuanced picture of entrepreneurialism, thus offering an important contribution to supplement existing scholarship. In this paper, we will focus on the intersection of race, ethnicity and gender, dealing primarily with issues of racism, sexism, racialized sexism, and sexualized racism brought about within the context of the class. As entrepreneurs who are primarily professional, educated, and middle classed, our respondents can use class as a resource to deal with the issues of racism and sexism. We shall discuss how these minority women entrepreneurs respond to diverse situations of discrimination in business.

\section{Research Method}

As the previous section noted, the intersectional perspective recognizes the importance of agency of minority women, and thus has important methodological implications. It emphasizes bringing women of colour to the 'centre' by seeing them as subjects with 'free 
minds' capable of telling their own stories (Collins 1991). The most preferred research method then is the kind that is culturally and gender sensitive, which allows women to give their voices so that their experiences are adequately represented. In order for women to relate their experiences and values in their own ways using their own language, we believe it is necessary to adopt a qualitative research agenda through which these tales can be analysed in a nuanced manner. Further, to collect narratives in a more systematic manner, we decided to conduct semi-structured interviews.

Both Hong Kong Chinese immigrant women in Richmond, Metro Vancouver, Canada and Asian immigrant women in Sydney, Australia were recruited through a snowballing of referrals. The Canadian sample was referred mostly by relatives, friends, association leaders, and business acquaintances, while the Australian sample was acquired mainly through one of the researchers' contact network in banking and in business. Most interviews with the Canadian sample, approximately two hours in length, were conducted in Cantonese with the exception of a few who used Mandarin or English. Interviews with the Australian women were conducted in English with a few exceptions where a mix of Cantonese and English were used. To protect their identity, all the names of the women entrepreneurs used in this paper are pseudonyms.

\section{Samples}

The Canadian study comprised of fifty-eight women who were mostly born in Hong Kong (forty-eight or 83 per cent), with seven born in Mainland China, one in Macau, one in Vietnam, and one in the Philippines. The Australian sample comprised of eighty women born in one of the following ten Asian economies - China, Hong Kong, Indonesia, Laos, Malaysia, Philippines, Singapore, Taiwan, Thailand and Vietnam.

Many of the women in the Canadian sample were relatively new immigrants to Canada, arriving in the early 1990's, mainly for the fear of the 1997 reversion of Hong Kong to Chinese sovereignty. Most came under the independent family migration category or the entrepreneurial program, and none of them came as refugees. The majority of these women were between the ages of 35 and 49, married mostly to middle-class or entrepreneurial husbands of the same ethnic background, and had few children who were mostly adolescents. Most had finished high school but few had received university or professional training. 
In the Australian study, the majority of the Asian-born women entrepreneurs were between 30 and 50 years of age, married and with dependents. More than half of them held a university degree, mainly gained from overseas. Close to a quarter of the Australian sample who came from Laos and Vietnam had entered Australia as Indo-Chinese refugees. The rest entered Australia under the business skills, employer nomination and independent visa categories. About a third of these women were sponsored by family members to settle in Australia. Unlike the Canadian sample, women in the Australian sample were more educated, and had more diverse immigration experiences, but were of similar age group and were mostly married with children.

The businesses owned by Chinese-Canadian women were mostly small businesses concentrated in the retail and service sectors. With a strong and well-established Chinese community, an overwhelming majority of these businesses (86.2 per cent) found their niche in the ethnic economy, hiring co-ethnic staff and serving the Chinese market with their businesses located in Chinese or Asian theme malls. Within the ethnic economy, twenty-one enterprises (39.6 per cent) were women-specific, targeting Chinese women's market in the areas of beauty, fashion, and lifestyle, and many of which had women employees. In other words, a considerable number of Chinese Canadian women entrepreneurs made use of their class and gender resources to provide services and employment for co-ethnic women.

Similar to the Canadian sample, the Australian sample has established a broad range of businesses, the majority of which were in retail and wholesale trade, and in property and business services. However, unlike the Canadian counterpart, their businesses were mainly located in mainstream commercial precincts. Other than the Hong Kong Chinese who located their businesses in Chinatown, and the poor and less educated refugee group who depended on co-ethnic support from families, many women in the Australian sample were members of communities that are dispersed and fragmented. Hence, these women were more likely to make use of their class resources to enter business, and less likely to take advantage of ethnic resources.

\section{Experiences of Racism and Sexism}

Racism and sexism, in many different ways, are felt and experienced in both Canadian and Australian societies despite the claim of building an open and liberal civil society. Systemic racism and sexism, embedded in social, economic, and political systems to preclude women 
and minority groups from equal participation, are still prevalent and deeply entrenched in the histories of colonialism and imperialism, and patriarchy. In the eyes of the mainstream society, Asian women immigrants do not belong as they are viewed as 'women who stand on the outside looking in', occupying 'a transition zone between aliens and citizens' (Lee 2006, p.38).

It is widely documented that Asian women face forms of discrimination in everyday life, in school, and in the workplace (Bannerji 1993; Hellwig and Thobani 2006). The women in our samples are no exceptions. Prior to starting their own businesses, many had attempted to look for work but were denied the opportunity; others suffered from underemployment and denial of promotional opportunities. Their reported experiences range from verbal abuse and name calling in everyday encounters with whites/ males to belittling and sexualization in job interviews; from isolation, rejection, and ridicule from white/male colleagues to working long hours with low pay, and denial of vacation time from white/male employers and managers. Whether the discrimination at work was blatant or subtle, many took a proactive approach and decided to turn to entrepreneurship as a way out.

These women, who have to continue succumbing to racist and sexist barriers to sustain livelihood in unpleasant working environments, possessed and used a variety of class resources, such as investment capital and/or related skills and experiences to avoid future humiliation. With or without self-awareness, these women used their class resources to gain power and the right to control their livelihood, and survive animosities in situations of marginalization and subjugation.

However, despite such class privileges racism and sexism do not end with entrepreneurship. Even though becoming entrepreneurs means the end to racial and gender discrimination from employers and colleagues at work, racism and sexism are still unavoidable in business situations when dealing with clients, customers, and business associates. In the following section, we present how the women in our studies managed racism and sexism in different ways.

\section{Responses to Racism and Sexism in Business}

From the experiences of the entrepreneurial women in our samples, we delineated four main strategies commonly used in responding to racism and sexism in business: first, 'creating a 
comfortable niche,' secondly, 'playing the mainstream card,' thirdly, 'swallowing the pain,' and fourthly, 'resisting.' It should be noted that these strategies are not mutually exclusive, and depending on specific situations and experiences, may be used simultaneously or interchangeably.

\section{Creating a comfortable niche}

To deal with racism and sexism, the most comfortable and easy way is to avoid direct contact with the perpetrators: white men and women, and/or co-ethnic men. Some of the women in our studies, empowered by class, ethnic, and/or gender resources, including economic resources, ethnic connections, ethnic-specific and gender-specific knowledge and skills, decided to use entrepreneurship as a means to create employment for themselves in the ethnic or feminised ethnic economy to avoid or reduce the chances of dealing with white men and women and co-ethnic men and the unnecessary harassments targeted at them. To 'make life easier,' these women set up businesses in the ethnic market and targeted co-ethnics; they hired co-ethnic staff, and ran their businesses dealing exclusively with co-ethnic business associates.

Some women engaged their businesses in an exclusively co-ethnic female environment. They used their class, gender and ethnic resources to set up women-specific businesses in the ethnic economy, hiring women staff and targeting women customers or clients. These culturally feminised resources that involved knowledge, skills and connections provided them with the opportunities to set up beauty-related and women fashion businesses that catered to the needs of co-ethnic women. In other words, a 'women only' safe haven was established with the sharing of a unique feminised ethnic culture that facilitated business and work relationships. Isabelle from Canada, for example, spoke candidly about how her beauty salon was set up in a way that provide a 'tranquil environment' for her clients, who would feel comfortable sharing stories of 'their lives, their families,' and 'fashion and beauty tips.' Beatrice talked about how keeping an all-female staff can constitute easy management and a 'cooperative' work environment. The comfortable niches these women built worked to escape the chances of racism and sexism. Such a move also provided them with a competitive edge and consequently, better chances of survival in business. 


\title{
Playing the Mainstream Card
}

One way to deal with racism or sexualised racism is to camouflage the business as mainstream. This involves the process of dichotomization between women themselves as minorities and the 'white/Canadian/Australian/westernised' as mainstream. To play this out, their businesses have to appear 'mainstream,' which entails a process of de-ethnicizing the business such as dropping the ethnic business name and adopting a western (English) name, westernizing the décor of the premises, putting the business in mainstream settings, hiring white employees, and as far as possible hiding the true identity of ownership. In certain circumstances, this mainstreaming approach would involve 'masculinization' when white male staff are considered preferable over female. This strategy was perceived as effective in dissolving conflicts that could hurt the business.

Beatrice from the Canadian sample owned a hair salon that served mainly white customers. In order for her business to appeal to white people, she used an English name for the salon, hid her identity as the owner, and hired a white woman as the manager in charge of daily operations while she posed as a Chinese hairstylist working along the six white women hairstylists she personally hired:

\begin{abstract}
People know me only as a hairstylist working in the salon. I don't want them to know that the boss is Chinese. White customers do not like to patronize Chinesestyle hair salons. I worked in this industry long enough to realize this. So when I started this business, I decided not to let clients know that this is Chinese owned. When they come to the salon and see a Chinese person at the reception area, and all hairstylists being Chinese, and hear Chinese people talking loudly in Chinese, they would not feel comfortable. They resent that kind of environment. That's why I hired a white woman working as the manager in the reception area. This makes the white customers feel at ease...My manager is also responsible for dealing with sales representatives sent over by the wholesalers, who are mainly whites.
\end{abstract}

Such a set-up helped Beatrice from running the risk of losing customers should she have to deal with discrimination in her daily business:

...But sometimes I would know immediately that the [white] person did not like me. They doubted my abilities and would ask questions like, 'Do you know how to do a haircut?' I usually would feel very embarrassed in front of my staff and other regular customers. But what can I do? I am used to it. So I would just let my other staff serve them. 
Similarly, Jessica from Australia who ran a printing business hired white sales representatives to do the work while she stayed in the background. When she had to step in, she never revealed herself to the customers as the owner:

\begin{abstract}
We do hire Australian [white] sales reps on the road, so if I come across racist people, we know they're racist, we send out our [white] sales people. So we stay in the background. So that's how we work... I go out never saying to them that I'm the owner. I have two sets of business cards. One business card, just my name, no title, nothing. So I never let them know that I'm the owner... so I could say, 'OK, I'll refer back to my Manager. I’ll see if I can give you a better price’ and things like that.
\end{abstract}

In addition, Jessica ensured that the racial composition of employees in her company was balanced and the wage rate competitive to Australian standard to prevent negative criticisms of her hiring policy. She also made sure that all the production was done locally to avoid people from labeling her company as non-Australian.

The employment of white staff is beneficial to business should racist or sexualized racist incidents occur:

Sometimes I hire [white] marketers, telesales people in the customer service, so they ring, ring, ring and they get the quote and we quote for them, they are happy with the price.... Then it happened ... When I went to see the client and he saw me, he didn't say anything and was very polite. Then later on I followed up; he didn't want to give the order. I knew it was due, you know, [to racism]. I pressed for the order ... but after seeing me, he kept putting it off. So when I got my Australian [white] rep to ring to find out why he didn't give us the order, he said 'I don't want to deal with the Vietnamese girl ...' ... when I sent out the Australian girl, he told her that. In the end, he still promised the Australian girl because he doesn't want to deal with me. (Note: Jessica was born in Malaysia, and is not of Vietnamese background.)

This mainstreaming strategy worked to protect the business even though it did not curb racism and sexualised racism entirely from happening. As long as these women entrepreneurs interacted with white people in running their businesses, they had to be prepared to face these challenges. Nonetheless, chances of harassment were greatly reduced and when it happened, they were able to resolve the problem more handily. 


\section{Swallowing the pain}

Direct confrontation may not been considered the best solution by some women and thus their defense mechanism works around non-confrontational and passive behavior, and quiet acceptance of their fate. Some women choose to ignore, dismiss, and withdraw from unpleasant situations by 'swallowing the pain' whereas others resort to an accepting approach. Some are even generous with a forgiving attitude.

In order to run their businesses smoothly, many women chose to swallow the pain and let the perpetrators continuously exploit them, as one woman who owned a café recounted her negative experience:
Some of the customers thought that because you were Chinese they could take advantage of you. For example, when they did not read the menu carefully they would blame me for 'false advertising'... A white male doctor came in every morning and ordered bacon and egg for breakfast despite I told him repeatedly that I was not allowed to serve this kind of food because of building regulations that did not allow us to fry. Every time he would get upset, and sometimes would even make arrogant comments like 'what kind of a café is this? You don't even serve proper breakfast!' (Edna, Canada)

This white male doctor seemed to enjoy his superior status and kept coming back despite knowing that the restaurant did not serve the kind of breakfast he wanted. And time over time, Edna swallowed the unreasonable accusations and felt helpless dealing with it.

Like Edna, many ignored or dismissed the problem. Betsy from Australia, for example, said: 'It's because you are Asian they look at you as if you are different from them. But you just don't take notice of them, you just let go.' Sheila from Canada felt that she was being taken advantage of because 'I am a woman' and 'they put pressure on me in negotiating a good deal for themselves.' She 'felt so bad' but decided to dismiss it. Others decided not 'to acknowledge it' and 'concentrate on the ones who love you and you'll be happier.' Still others wore out any discrimination by being humble and used an accepting approach as the following demonstrates:

They say something rude in front of you and you just hold your tongue. Even if you argue, there's no point. So if they are not happy, you just say sorry and let them out of the shop and that's it. And we try not to argue with any customer because you're here every day, you see all kinds of people, you prepare for that. (Tania, Australia) 
When dealing with sexism perpetuated by co-ethnic men, these women also choose to accept it with pain, for example:

Sometimes I didn't feel being recognized as a boss. For example, when the wholesale reps came, they usually would look for my husband. And if my husband was not in, they did not even bother to talk to me and said they would come back some other time... Well, that's the way it is. (Joan, Canada)

In other situations, traditional gender expectations would impact women's behaviour and make them look for more acceptable alternatives. For example, in coping with the sexist expectation that it is inappropriate for women to entertain men, some women resorted to withdrawal and avoided entertaining altogether or sought help from other men:

Sometimes it's difficult when you have to go out with a male client, say to lunch... when my friends saw me having dinner with a man, and it's not my husband, they would give me a weird look... This could lead to misunderstandings... gossips, you know. That's why I try to avoid entertaining my clients. Sometimes if it were really necessary I would invite their wives and my husband to go along. Then I would feel more comfortable. (Ophelia, Canada)

A lot of our clients are typically Asian male and you can't go out and be like one of the boys. They are very much used to typical business people, they entertain and all this. It's different if you are male, then you are one of the boys and you go and dine with them and whatever. We can still dine with them but it's a very different sort of dining... I bring my [business] partner in and he does the other side... so after dinner, my partner does the other role if they want to go somewhere else. (Penny, Australia)

These women, having internalised their gender roles, withdrew from the situation when it challenged their comfort zone, and they did so even if such moves would do harm to their businesses. What is prescribed to them in a patriarchal society outweighs the importance of business. Instead of challenging sexist social expectations, they chose to comply.

\section{Resisting}

Although many women took a passive way in managing discrimination, the assertive ones chose to resist and struggle in order to regain control even if this means compromising their businesses. This strategy is more commonly used among women who face sexism, racialised sexism or sexualised racism in handling daily business. Jocelyn from Australia, who owned two legal practices, recalled how she learned to be tough and fought back after years of 
harassment from other Australian white male lawyers. For example, in the case when these lawyers refused to talk to her, she would say:

If you don't want to talk to me that's fine. I don't have to talk to you anymore, so don't ring here to speak to the person handling the matter.

Jocelyn learned to 'tell them off' upfront and would not shy away from it:

At first I would ask them politely to talk to me in a respectable manner. If they still go on in a harassing way I would give them a warning and I would say, 'If you keep on like this I will hang up the phone', and if they don't change their attitude I just hang up but, sometimes if they make me mad, obviously I have to raise my voice and scream back and then slam the phone.

A different technique used in resistance that is less confrontational pertains to changing the negative impressions of the perpetrators when these women's work is undermined. Gloria from Canada spoke of getting 'tough' and 'presenting a superwoman image' when dealing with bankers, suppliers and customers in order for these people to 'take [her] seriously as a woman’ and to prevent people from taking advantage of her. Another woman, Sharon, talked about how she had to 'work extra hard to convince people' and to 'gain respect' from her employees whereas her husband ‘didn’t have to do anything' and people ‘would just listen to him.'

\section{Conclusion}

A general perception of entrepreneurs is that they are independent profit-seekers, privileged with entrepreneurial spirit and economic resources and the power to exercise control and realize goals. Such a view, however, is misleading when applied to immigrant women entrepreneurs, who run primarily time and labour intensive small businesses. Their position in the economy is beyond comparison with the mainstream corporate power. Rather, like other underprivileged workingwomen, they are marginalised and isolated in struggling for survival. Despite their efforts to fight discrimination with entrepreneurship, mobilizing available class, gender, and/or ethnic resources to start businesses, our findings show that entrepreneurship does not end the experience of racism and sexism. These women continue to struggle with discrimination in business, fighting it mainly alone without institutional support.

In this paper, we reviewed the various strategies employed by Asian women in our studies when dealing with racism and sexism. Although some managed to create a 'comfortable 
niche' in the ethnic economy or a feminized ethnic economy, such a choice would have limited their business opportunities to these marginalized sectors. Those who engaged in 'mainstreaming' their businesses were able to use their class resources to compete with other mainstream businesses but still could not protect themselves from racism and sexism in daily business operations. Others resorted to 'resist' and fought for dignity, respect, and control, or 'swallowing the pain' for the purpose of survival.

Needless to say, minority women entrepreneurs, when compared with white men and women as well the co-ethnic male counterparts, have to direct extra resources, energy, time and efforts to maintain their businesses.

In closing, this paper provides a new angle to understanding entrepreneurship and opens up space for future research. We argued that there is an urgent need to bridge the gap between the 'mainstream' entrepreneurship literature and the immigrant entrepreneurship literature. Both literatures are weak in their theorizing of, and understanding of, minority immigrant women entrepreneurs. The existing ethnic entrepreneur and women’s entrepreneur scholarship focus primarily on racism and sexism as barriers driving minorities into starting their businesses, yet rarely address how racism and sexism shape the dynamics of the enterprises the minority women establish and the strategies they employ to manage this discrimination. Despite the novelty of our approach, there are some unanswered questions that need to be addressed: Are the strategies used by women in our samples unique to Asian immigrant women only or found among other immigrant women as well? Would minority men respond to discrimination in similar ways? In sum, we call for more research in the future for purposes of comparison between minority men and women, and among diverse women groups. 


\section{References}

Adelman, H. et al. (eds) 1994a, Immigration and Refugee Policy: Australia and Canada Compared Vol I, University of Melbourne Press, Melbourne, pp. 631-53. 1994b, Immigration and Refugee Policy: Australia and Canada Compared Vol II, University of Melbourne Press, Melbourne.

Aldrich, H. \& Waldinger, R. 1990, 'Ethnicity and entrepreneurship', Annual Review of Sociology, vol. 16, pp.111-35.

Anthias, F. \& Mehta, N. 2003, 'The Intersection between gender, the family and selfemployment: The family as a resource', International Review of Sociology, vol. 13, no. 1, pp.105-16.

Anthias, F. \& Yuval-Davis, N. 1992, Racialized Boundaries: Race, Nation, Gender, Colour and Class and the Anti-racist Struggle, Routledge, London.

Apitzsch, U. 2003, 'Gaining autonomy in self-employment processes: The biographical embeddedness of women's and migrants' business', International Review of Sociology, vol. 13, no.1, pp. 163-82.

Bannerji, H. (ed) 1993, Returning the Gaze: Essays on Racism, Feminism and Politics, Sister Vision Press, Totonto.

Beggs, J., Doolittle, D. \& Garsombke, D. 1994, 'Entrepreneurship interface: linkages to race, sex and class', Race, Class, and Gender, vol. 1, no. 2, pp. 35-51.

Bruni, A., Gherardi, S. \& Poggio, B. 2005, Gender and Entrepreneurship: An Ethnographical Approach, Routledge, London

Castles, S. et al. 1991, 'The global milk bar and the local sweatshop: ethnic small business and the economic restructuring of Sydney', Working papers in multiculturalism no 2, published for The Office of Multicultural Affairs, Department of the Prime Minister and Cabinet. The Centre for Multicultural Studies, University of Wollongong.

Collins, J. 2002, 'Chinese Entrepreneurs: The Chinese Diaspora in Australia', International Journal of Entrepreneurial Behaviour \& Research, vol. 8, no. 1/2, pp. 113-33.

------ and Castles, S. 1992, 'Restructuring, migrant labour markets and small business in Australia', European Journal of International Migration and Ethnic Relations, vol. 10, pp. 7-34.

------ and Henry, F. 1994, 'Racism, ethnicity and immigration in Canada and Australia', in Howard Adelman, et al. (eds) Immigration and Refugee Policy: Australia and Canada Compared Vol II, Melbourne University Press, Melbourne, pp. 515-48.

------ et al. (eds) 1995, A Shop Full Of Dreams: Ethnic Small Business in Australia, Pluto Press, Leichhardt.

Collins, J. \& Low, A. 2010, 'Asian female immigrant entrepreneurs in small and mediumsized businesses in Australia’, Entrepreneurship \& Regional Development, vol. 22 no. 1, pp. 97-111.

Collins, P. 1991, Black Feminist Thought, Routledge, New York.

Dhaliwal, S. 1998, 'Silent contributors: Asian female entrepreneurs and women in business', Women's Studies International Forum, vol. 21, no. 5, pp. 463-74.

Dallalfar, A. 1994, 'Iranian Women as Immigrant Entrepreneurs', Gender \& Society, vol. 8, no. 4, pp. 554-61.

Dua, E. and Robertson, A. (eds) 1999, Scratching the Surface: Canadian anti-racist Feminist Thought, Women's Press, Toronto.

Essers, C. \& Benschop, Y. 2009, 'Muslim businesswomen doing boundary work: The negotiation of Islam, gender and ethnicity within entrepreneurial contexts', Human Relations, vol. 62, no. 3, pp. 403-23. 
Froschauer, K. and Wong, L. 2006, 'Understanding immigrants' initiatives in the new economy: the case of Western Canada', Canadian Ethnic Studies Journal, vol. 38, no. 2, pp. 86-103.

Greer, M. and Greene, P. 2003, ‘Feminist theory and the study of entrepreneurship’ in Butler, J. (ed), New Perspectives on Women Entrepreneurs, Information Age Publishing, Connecticut, pp. 1-24.

Harvey, A. 2005, 'Becoming entrepreneurs: intersections of race, class, and gender at the Black Beauty Salon', Gender \& Society, vol. 19, pp. 789-808.

Hauge, E. \& Havnes, P. (eds) 2005, Women Entrepreneurs: Theory, Research and Policy Implications, Norwegian Academic Press, HoyskoleForlaget.

Hellwig, T. \& Thobani, S. (eds) 2006, Asian Women: Interconnections. Women’s Press, Toronto.

Hindle, K. \& O'Connor, A. 2005, Westpac GEM Australia: A Study of Australian Entrepreneurship in 2004, Australian Graduate School of Entrepreneurship Research Report Series, Vol 2, No.1. Swinburne University of Technology, Melbourne.

Hughes, Karen D. 1999, Gender and Self Employment in Canada: Assessing Trends and Policy Implications, Canadian Policy Research Networks, Ottawa.

Ip, D. \& Lever-Tracy, C. 1991, 'Asian women in business', in Women in Migration, Bureau of Immigration Research, Melbourne.

------ 1992, “Asian Women in Business”, Asian Migrant, vol. 5, pp. 12-23.

Jiwani, Y. 2006, 'From Dragon Lady to Action Hero: Race and gender in popular Western television, in Hellwig, T. \& Thobani S. (eds), Asian Women: Interconnections, Women's Press, Toronto, pp.161-84.

Kang, M. 1997, 'Manicuring race, gender, and class: Service interactions in New York City Korean nail salons', Race, Gender, and Class, vol. 4, no. 3, pp.143-64.

2003, 'The managed hand: commercialization of bodies and emotions in Korean-owned nail salons', Gender \& Society, vol. 17, no. 6, pp. 820-39.

Kloosterman, R. \& Rath, J. (eds.), 2003, Immigrant Entrepreneurs: Venturing Abroad in the Age of Globalisation, Berg Publishing, Oxford.

Kloosterman, R. \& Rath, J. 2001, 'Immigrant entrepreneurs in advanced economies: Mixed embeddedness further explored, Journal of Ethnic and Migration Studies vol. 27, no.2, pp. 189-202.

Knight, M. 2005, 'The production of the female entrepreneurial subject: A space of exclusion for women of color', Journal of Women, Politics \& Policy, vol. 27, pp. 151-59.

Lee, J. 2006, 'Issues in constructing Asian-Canadian Feminisms', in Hellwig, T. \& Thobani, S. (eds), Asian Women: Interconnections, Women’s Press, Toronto, pp. 21-46.

Lever-Tracey, C. 1991, Asian Entrepreneurs in Australia, Australian Government Publishing Service, Canberra.

Li, P. 1988, The Chinese in Canada, Oxford University Press, Toronto.

------ 2001, 'Chinese Canadians in business', Asian and Pacific Migration Journal, vol.10, no. 1, pp. 99-121.

Light, I. 1972, Ethnic Enterprise in America, University of California Press, Berkeley.

------ \& Rosenstein, C. 1995 Race, Ethnicity, and Entrepreneurship in Urban America, Aldine de Gruyter, New York.

------ \& Gold, S. 2000, Ethnic Economies, Academic Press, San Diego.

Massaquoi, N. \& Wane, N. (eds) 2007, Theorizing Empowerment: Canadian Perspectives on Black Feminist Thought, Innana Publications, Toronto.

Minniti, M., Arenius, P. \& Langowitz, N. 2005, Global Entrepreneurship Monitor, 2004 Report on Women and Entrepreneurship, Centre for Women's Leadership at Babson College and London Business School. 
OECD 1998, Proceedings Women Entrepreneurs in Small and Medium Enterprises, Organisation for Economic Co-operation and Development, Paris.

Peters, N. 1999, Trading Places: Greek, Italian, Dutch and Vietnamese enterprise in western Australia, Unpublished PhD dissertation, University of Western Australia, Perth.

Pio, E. 2007, 'Ethnic entrepreneurship among Indian women in New Zealand: A bittersweet process', Gender, Work and Organization, vol. 14, no. 5, pp. 409-432.

Stromback, T. \& Malhotra, R. 1994, Socioeconomic linkages of South Asian immigrants with their country of origin, BIPR and Australian Government Publishing Service, Canberra.

Yuval-Davis, N. 2006, 'Intersectionality and feminist politics', European Journal of Women Studies, vol. 1, no. 3, pp. 193-210.

Waldinger, R. et al. 1990, Ethnic Entrepreneurs, Sage Publications, Newbury Park.

Wong, L. 2004, 'Taiwanese immigrant entrepreneurs in Canada and transnational social space', International Migration, vol. 42, no. 2, pp.113-152 and Ng, M. 2002, 'The emergence of small transnational enterprise in Vancouver: The case of Chinese entrepreneur immigrants', International of Urban and Regional Research, vol. 26, no. 3, pp.508-30. 